IJBPAS, March, 2021, 10(3): 901-915

ISSN: 2277-4998

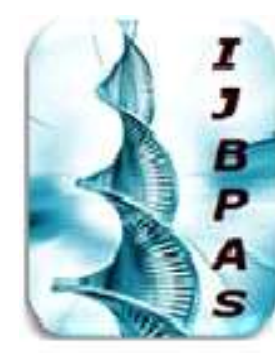

International Journal of Biology, Pharmacy

and Allied Seiences (IJBPAS)

'A Bridge Betusen Caboratory and Q Qundo'

WwW.ijbpas.com

\title{
LEAVES OF Cleisostoma tenuifolium, AN EPIPHYTIC ORCHID: HABITAT FOR DIVERSE ENDOPHYTIC BACTERIA
}

\section{DARSHA S* AND JAYASHANKAR M}

Mangalore University, Department of Research and Studies in Microbiology, PG Centre, Jnana Kaveri Campus, Kodagu- 571232, Karnataka, India

*Corresponding Author: Darsha S: E Mail: darshu11m90@gmail.com; Tel: +918277315181

Received $12^{\text {th }}$ May 2020; Revised $7^{\text {th }}$ June 2020; Accepted $13^{\text {th }}$ July 2020; Available online $1^{\text {st }}$ March 2021

https://doi.org/10.31032/IJBPAS/2021/10.3.5401

ABSTRACT

Kodagu is a tiny piece of land located in the heart of Western ghats. Epiphitic orchid, Cleisostoma tenuifolium from this were used for our study. Similar to all orchids, this is also a flowering plant with yellow charming flowers. We have identified five endophytic bacterial strains from the leaves of this plant by molecular identification namely Bacillus subtilis, Psychrobacillus psychrodurans, Bacillus cereus, Bacillus safensis, Bacillus pumilus. The study revealed that all of them are bacillus but, are different from each other. Common protocols were used for isolation and 16S rDNA sequencing following PCR were used for genotypic characterization of bacteria. Obtained sequences were compared for with known bacterial culture from NCBI database and submitted to GenBank. Homology of the bacteria were studied using Phylogenetic tree analysis. Future studies were needed to identify more endophytes from different parts of this vulnerable plant and thereby a small effort for conservation of biodiversity.

Keywords: Endophytic bacteria, 16S rDNA, PCR, GenBank, orchid, biodiversity INTRODUCTION

Western Ghats, is a mountain range site, it is one of the eight "Hottest hot-spots" (N $8^{\circ} 20^{\prime}-20^{\circ} 40^{\prime}$ and $\mathrm{E} 73^{\circ}-77^{\circ}$ ) that runs of biological diversity in the world. The parallel to the western coast of the Indian peninsula. As per UNESCO World heritage mountain range is also known as "Sahyadri" begins from the Songadh town of Gujarat, 
south of Tapti river and covers approximately $1,600 \mathrm{~km}$ through the states of Maharashtra, Goa, Karnataka, Kerala and Tamilnadu, ending at Marunthuvazhmalai at Swamithope, near Kanyakumari, the southern tip of India. The hottest biodiversity hotspot has over 7402 species of flowering plants, 1814 species of non-flowering plants and other flora and fauna [29].

The family Orchidaceae is a highly evolved and widely distributed family in monocotyledons of angiosperm. Orchids have diverse habits with variously modified floral parts. The orchids are represented by a large number of terrestrial, saprophytic and epiphytic species. They are distributed worldwide and exhibit incredible diversity in shape, size and color of the flowers. Orchids are important aesthetically, medicinally and are regarded as ecological indicators. They found economic uses especially in floriculture and hence many species of orchids are cultivated for ornamental purposes. Orchids have been used as food and in traditional medicine for treating several ailments by different cultures and tribes all over the world. Orchids are very sensitive to habitat degradation. Although large population of orchids is confined to their natural habitats, their number is decreasing because of high demand, habitat destruction and indiscriminate collection [1, $15,16,20,24,28]$.

Endophytes are microorganisms inhabiting plant organs that at the same time in their life, can colonize apparent harm to the host" [2]. In most plant species, endophytic bacteria are ubiquitous, colonizinglocally as well as systemically, and influencing plant health by suppression of disease, degradation of contaminants, and promotion ofplant growth [30]. Endophytic bacteria provide useful and rich models to study the genetic expression of bacteria in their natural niches or habitats (inside plants), which are more structured and variable thanculture media under controlled laboratory conditions. Nevertheless, very little work has been done on this. Genomic projects are being performed on some endophytic bacteria, such as Azoarcus spp.[3].

Rhizobium and other beneficial microbialmicrobial diversity of three legumes plants that would help as biofertilizers for the crop from Fabaceae family [6]. The population density of endophytes is highly variable, depending mainly on the bacterial species and host genotypes butalso in the host developmental stage, inoculum density, and environmental conditions [31]. Endophytic bacteria in a 
single plant host are not restricted to a single species but comprise several genera and species. No one knows if communities inside plants interact, and it has been speculated that beneficial effects are the combined effect of their activities. Endophytes seem promising to increase crop yields, remove contaminants, inhibit pathogens, and produce fixed nitrogen or novel substances. The repertoire of their effects and functions in plant has not been comprehensively defined [23]. Cleisostoma tenuifolium is an epiphytic plant that habitat on tree trunks in broad leaved evergreen forests and semi-evergreen forest. It is a flowering plant with yellow flowers with linear pointed leaves that belongs to the family Orchidaceae which will grow upto 20-30 long [12].

The present investigation deals with the genotypic identification of endophytic bacterial isolates from a particular epiphytic orchid plant Cleisostoma tenuifolium.

\section{MATERIALS AND METHODS}

All samples were collected in sterile polythene bags and brought to the laboratory and used for isolation within $24 \mathrm{~h}$ of collection. To analyze the endophytic microbiota, plant samples were washed thoroughly with tap water followed by steriledouble distilled water [11]. Each plant sample was cut aseptically into $1 \mathrm{~cm}$ long segments using a sterile blade underthe laminar flow hood and allowed to dry. The cut surfaces of plant segments were placed on Petri plates containing Nutrient Agar (NA) media (Himedia, India). Each plant segment was inoculated in triplicate. Plates were then incubated at $32^{\circ} \mathrm{C}$ for $48 \mathrm{~h}$. Colonies with different morphology and pigmentation were randomly selected from each plate and streaked on fresh NA plates as described above. Simultaneously, the pure isolates were preserved for further studies.

Total genomic DNA was extracted from all fungal morphotypes using the phenol-chloroform method. The scrapped mycelia were transferred to a sterile microcentrifuge tube containing $500 \mu \mathrm{L}$ DNA buffer $(0.1 \mathrm{MNaCl}, \quad 50$ mMTris, 10 mMNa2EDTA, 2\% SDS, pH 8.0) and were mixed with a sterile toothpick. The mixture was again ground by adding $500 \mu$ Lof chilled phenol. This step was followed by 15 minutes centrifugation at $12000 \mathrm{rpm}$ at $4^{\circ} \mathrm{C}$; $200-300 \mu \mathrm{L}$ of the upper aqueous phase and equal volume of chloroform: isoamylalcohol (24:1) were stirred for obtaining a white suspension in a sterile tube and were again centrifuged at the same conditions (12000rpm at $4{ }^{\circ} \mathrm{C}$ for 15 minutes). Then, to O.6 volume of chilled isopropanol and $1 / 10^{\text {th }}$ volume of $3 \mathrm{M}$ sodium acetate, this aqueous 
phase was transferred and mixed gently. The microfuge containing mixture were kept at $80^{\circ} \mathrm{C}$ for 2 hours and were centrifuged at $12000 \mathrm{rpm}$ at $4^{\circ} \mathrm{C}$ for 15 minutes. The pellet obtained after discarding supernatant were washed with $200 \mu \mathrm{L}$ of $70 \%$ ethanol and centrifuged at $12,000 \mathrm{rpm}$ for 10 minutes at $4^{\circ} \mathrm{C}$. The supernatant was discarded and the pellet obtained were air dried and suspended in $50 \mu \mathrm{L}$ of sterile distilled water and stored at ${ }^{2} 20^{\circ} \mathrm{C}$.

The PCR programme employed was as follows: primary denaturation for 5 minutes at $94^{\circ} \mathrm{C} ; 35$ cycles of denaturation at $94^{\circ} \mathrm{C}$ for $30 \mathrm{~s}$; annealing $54^{\circ} \mathrm{C}$ for $30 \mathrm{~s}$, and extension at $72^{\circ} \mathrm{C}$ for $1 \mathrm{~min}$; and a final extension for 10 minutes at $72^{\circ} \mathrm{C}$ [27]. After amplification obtained genome were sequenced, the similarity of the sequence was compared with known culture from NCBI data base and accordingly sequence similarity matrix was generated. Phylogenetic tree of each culture was also prepared by using MEGA4 programe. Phylogenetic tree constructed by comparing with strains from GenBank with highest similarities.

\section{RESULTS}

Healthy leaves of the epiphytic orchid were collected from the Somwarpet region of Kodagu district, Karnataka, India. The plant was found on the tree trunk (Figure 1) collected was shown in the Figure 2 and the leaf parts were shown in the Figure 3.

By using the leaf sample bacterial pure cultures were isolated. A number of isolates were obtained but a few were selected for molecular characterization. For the temporary convenience, those were named as BL1, BL2, BL3, BL4 and BL5. Genomic DNA of all the bacteria were isolated by phenol-chloroform method. Quantified DNA of five bacteria were amplified using PCR. 16S rDNA were sequenced and the sequences were compared with the known bacterial sequences from NCBI database. The sequences obtained were submitted to Genbank for Accession numbers; submission code and the accession number of each bacteria were given in the Table 1.

Based on the percentage of similarity with the closely related bacteria similarity matrix for each bacteria were prepared. All the matrices were given one after the other in the tables; Table 2, Table 3, Table 4, Table 5 , and Table 6 for the sequenced cultures BL1,BL2,BL3, BL4 and BL5 respectively. BL1: The culture 16S rDNA sequence has 99.83\% similarity with Bacillus sp. with maximum homology with Bacillus subtilis. BL2: The culture 16S rDNA sequence has 
98.46\% similarity with Psychrobacillus sp. with maximum homology with Psychrobacillus psychrodurans. BL3: The culture 16S rDNA sequence has 98.7\% similarity with Bacillus sp. with maximum homology with Bacillus cereus. BL4: The culture 16S rDNA sequence has 99.87\% similarity with Bacillus zhangzhouensis and 99.74\% similarity with Bacillus pumilus. BL5: The culture 16S rDNA sequence has $100 \%$ similarity with Bacillus sp. with maximum homology with Bacillus pumilus.

Construction of Phylogenetic tree is done by comparing with strains from GenBank with highest similarities. Tree is constructed using kimura 2 model with bootstrap method. The neighbor-joining tree and subtree were generated using MEGA5.2 software. Numbers show the level of bootstrap support from 1,000 repetitions. The tree is drawn to scale, with branch lengths in the same units as those of the evolutionary distances used to infer the phylogenetic tree. All positions containing alignment gaps and missing data were eliminated only in pairwise sequence comparisons. Figures from 4 to 8 represents the trees of each bacterial cultures.

From the experiments, endophytic bacterial strains from epiphytic orchid, $C$ tenuifolium were identified as Bacillus subtilis MT463729, Psychrobacillus psychrodurans MT540515, Bacillus cereus MT540508, Bacillus safensis MT540512, Bacillus pumilus MT540513.
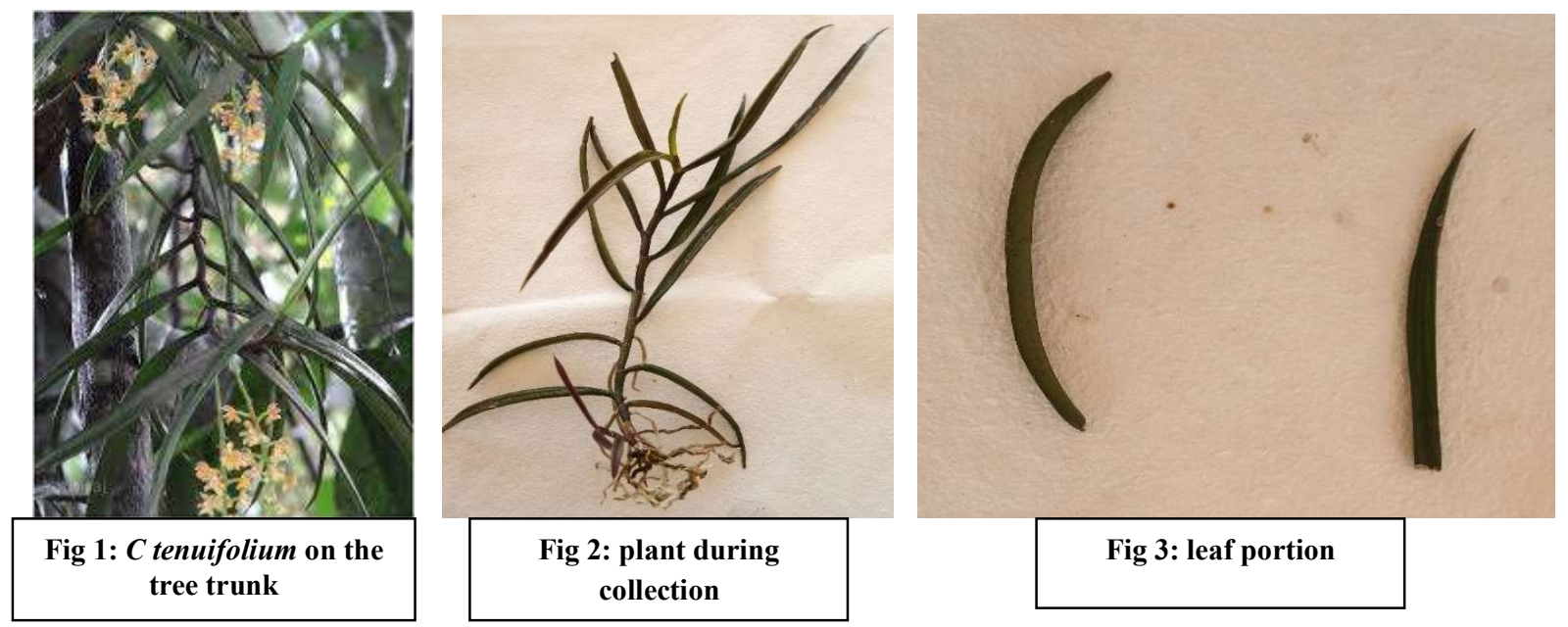
Table 1: showing submission code and accession number for corresponding sequences

\begin{tabular}{|c|c|c|c|}
\hline Sl. No. & Fungi & Submission code & Accession number \\
\hline 1. & BL1 & SUB7444699 & MT463729 \\
\hline 2. & BL2 & SUB7526079 & MT540515 \\
\hline 3. & BL3 & SUB7526079 & MT540508 \\
\hline 4. & BL4 & SUB526079 & MT540512 \\
\hline 5. & BL5 & SUB7526079 & MT5513 \\
\hline
\end{tabular}

Table 2: Sequence similarity matrix of BL1 16S rRNA partial sequence with the other closely related species

\begin{tabular}{|c|c|c|c|c|c|c|c|c|c|c|c|c|}
\hline Sequence & 1 & 2 & 3 & 4 & 5 & 6 & 7 & 8 & 9 & 10 & 11 & 12 \\
\hline BL1 & - & & & & & & & & & & & \\
\hline $\begin{array}{c}\text { Bacillus_sp_strain_HA15-19 } \\
\text { (MH769122.1) }\end{array}$ & 99.8 & - & & & & & & & & & & \\
\hline $\begin{array}{c}\text { B_subtilis_strain_FJAT-42395 } \\
(\text { MG651108.1) }\end{array}$ & 99.8 & 99.6 & - & & & & & & & & & \\
\hline $\begin{array}{c}\text { B_subtilis_strain_CSBR-EBACI4 } \\
\text { (AB726089.1) }\end{array}$ & 99.3 & 99.4 & 99.4 & - & & & & & & & & \\
\hline $\begin{array}{c}\text { B_subtilis_strain_LJFMLL6 } \\
\text { (MK086953.1) }\end{array}$ & 99.6 & 99.8 & 99.8 & 99.6 & - & & & & & & & \\
\hline $\begin{array}{c}\text { B_subtilis_strain_IICE-7 } \\
(\text { MK367805.1) }\end{array}$ & 99.6 & 99.8 & 99.8 & 99.6 & 100 & - & & & & & & \\
\hline $\begin{array}{c}\text { B_subtilis_strain_IIIVE-4 } \\
\text { (MK367788.1) }\end{array}$ & 99.6 & 99.8 & 99.8 & 99.6 & 100 & 100 & - & & & & & \\
\hline $\begin{array}{c}\text { B_thuringiensis_strain_CBS-1P } \\
\text { (MH251257.1) }\end{array}$ & 92.9 & 93 & 93 & 92.9 & 93.2 & 93.2 & 93.2 & - & & & & \\
\hline $\begin{array}{c}\text { B_megaterium_strain_PgBE7 } \\
(\text { MH144230.1) }\end{array}$ & 91.2 & 91.4 & 91.4 & 91.2 & 91.5 & 91.5 & 91.5 & 92.4 & - & & & \\
\hline $\begin{array}{c}\text { B_subtilis_strain_SE3-8 } \\
(\text { MG890420.1) }\end{array}$ & 99.3 & 99.4 & 99.4 & 99.3 & 99.6 & 99.6 & 99.6 & 93 & 91.4 & - & & \\
\hline $\begin{array}{c}\text { B_licheniformis_strain_ATCC14580 } \\
\text { (NR_074923.1) }\end{array}$ & 97.8 & 97.9 & 97.9 & 97.8 & 98.1 & 98.1 & 98.1 & 92.6 & 91.1 & 98.1 & - & \\
\hline $\begin{array}{c}\text { B_amyloliquefaciens_strain_NBRC15535 } \\
\text { (NR_041455.1) }\end{array}$ & 98.6 & 98.8 & 98.8 & 98.6 & 98.9 & 98.9 & 98.9 & 93 & 90.7 & 98.9 & 97.8 & - \\
\hline
\end{tabular}

Table 3: Sequence similarity matrix of BL2 16S rRNA partial sequence with the other closely related species

\begin{tabular}{|c|c|c|c|c|c|c|c|c|c|c|c|}
\hline Sequence & 1 & 2 & 3 & 4 & 5 & 6 & 7 & 8 & 9 & 10 & 11 \\
\hline $\begin{array}{c}P_{\text {_psychrodurans_strain_AW23_(J }}{ }_{X 281784.1)} \\
\end{array}$ & - & & & & & & & & & & \\
\hline Bacillus_sp_L35_(KT965156.1) & 99.00 & - & & & & & & & & & \\
\hline $\begin{array}{c}\text { P_psychrodurans_strain_IHBB_7121 } \\
(\text { KJ767324.1) }\end{array}$ & 99.20 & 98.80 & - & & & & & & & & \\
\hline P_psychrodurans_strain_ES1_(KP334978.1) & 98.60 & 99.00 & 98.80 & - & & & & & & & \\
\hline $\begin{array}{c}P \_ \text {psychrodurans_strain_APBSDSB158 } \\
(M G 705704.1)\end{array}$ & 93.80 & 93.40 & 93.80 & 92.80 & - & & & & & & \\
\hline 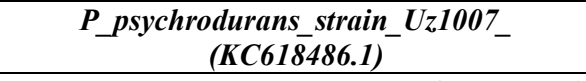 & 97.80 & 97.60 & 97.60 & 97.10 & 94.60 & - & & & & & \\
\hline Psychrobacillus_sp_strain_KF-1 (G266333.1) & 95.00 & 95.70 & 94.80 & 95.90 & 91.70 & 95.90 & - & & & & \\
\hline $\begin{array}{c}\text { Psychrobacillus_sp_strain_FA2-37 } \\
\text { (KY476186.1) }\end{array}$ & 90.20 & 90.50 & 90.50 & 91.30 & 88.20 & 90.50 & 93.60 & - & & & \\
\hline $\begin{array}{c}\text { Chryseomicrobium_sp_strain_KST } 180 \\
\text { (KX989446.1) }\end{array}$ & 78.90 & 79.10 & 79.30 & 79.30 & 81.20 & 79.50 & 80.40 & 79.70 & - & & \\
\hline $\begin{array}{c}\text { Psychrobacillus_sp_strain_CMF-2 } \\
\text { (MG266379.1) }\end{array}$ & 74.40 & 74.20 & 75.00 & 75.00 & 77.40 & 75.30 & 76.00 & 76.00 & 81.50 & - & \\
\hline BL2 & 97.60 & 97.30 & 98.40 & 97.30 & 93.40 & 96.10 & 94.00 & 90.20 & 79.60 & 75.70 & - \\
\hline
\end{tabular}


Table 4: Sequence similarity matrix of BL3 16S rRNA partial sequence with the other closely related species

\begin{tabular}{|c|c|c|c|c|c|c|c|c|c|c|c|}
\hline Sequence & 1 & 2 & 3 & 4 & 5 & 6 & 7 & 8 & 9 & 10 & 11 \\
\hline $\begin{array}{c}\text { B_licheniformis_strain_ATCC14580 } \\
\text { (NR074923.1) }\end{array}$ & - & & & & & & & & & & \\
\hline B_subtilis_strain_SE3-8(MG890420.1) & 98.00 & - & & & & & & & & & \\
\hline $\begin{array}{c}\text { B_amyloliquefaciens_strain_NBRC15535 } \\
\text { (NR041455.1) }\end{array}$ & 97.70 & 99.00 & - & & & & & & & & \\
\hline B_megaterium_strain_PgBE7(MH144230.1) & 91.10 & 91.60 & 90.90 & - & & & & & & & \\
\hline $\begin{array}{c}\text { B_thuringiensis_strain_MFB_94f } \\
(M K 583935 . \overline{1})\end{array}$ & 92.70 & 93.30 & 93.30 & 92.70 & - & & & & & & \\
\hline B_cereus_strain_LJOSL(MH793360.1) & 92.70 & 93.30 & 93.30 & 92.50 & 99.80 & - & & & & & \\
\hline B_cereus_strain_ck-01(MK592620.1) & 92.90 & 93.50 & 93.50 & 92.70 & 99.80 & 99.60 & - & & & & \\
\hline B_mycoides_strain_N407(MK629809.1) & 92.70 & 93.30 & 93.30 & 92.70 & 100.00 & 99.80 & 99.80 & - & & & \\
\hline $\begin{array}{c}\text { B_thuringiensis_strain_CBS-1P }_{(M H 251257 . \overline{1})} \\
\text { (MH }\end{array}$ & 92.90 & 93.50 & 93.50 & 92.70 & 99.80 & 99.60 & 100.00 & 99.80 & - & & \\
\hline$B L 3$ & 91.60 & 92.20 & 92.20 & 91.10 & 98.20 & 98.00 & 98.30 & 98.20 & 98.30 & - & \\
\hline B_cereus $(A Y 986507.1)$ & 47.00 & 46.60 & 46.70 & 45.70 & 47.00 & 46.90 & 47.20 & 47.00 & 47.20 & 46.60 & - \\
\hline
\end{tabular}

Table 5: Sequence similarity matrix of BL4 16S rRNA partial sequence with the other closely related species

\begin{tabular}{|c|c|c|c|c|c|c|c|c|c|c|c|c|}
\hline Sequence & 1 & 2 & 3 & 4 & 5 & 6 & 7 & 8 & 9 & 10 & 11 & 12 \\
\hline B_zhangzhouensis_strain_K16_(MK696265.1) & - & & & & & & & & & & & \\
\hline $\begin{array}{c}B_{-} \text {_zhangzhouensis_strain_UQCH011 } \\
(\text { MK214760.1) }\end{array}$ & 100.00 & - & & & & & & & & & & \\
\hline B_australimaris_strain_T7F4_9_(MH011957.1) & 95.90 & 95.90 & - & & & & & & & & & \\
\hline B_pumilus_srain_CIFTMFB20_(MK6 16340.1) & 99.70 & 99.70 & 95.90 & - & & & & & & & & \\
\hline B_australimaris_strain_H2_(MK256796.1) & 100.00 & 100.00 & 95.90 & 99.70 & - & & & & & & & \\
\hline $\begin{array}{c}\text { B_zhangzhouensis_strain_APBSDSB26 } \\
(M G 705572.1)\end{array}$ & 100.00 & 100.00 & 95.90 & 99.70 & 100.00 & - & & & & & & \\
\hline B_pumilus_strain_K10_(MK696261.1) & 100.00 & 100.00 & 95.90 & 99.70 & 100.00 & 100.00 & - & & & & & \\
\hline B_pumilus_strain_w7_(MK696242.1) & 100.00 & 100.00 & 95.90 & 99.70 & 100.00 & 100.00 & 100.00 & - & & & & \\
\hline B_pumilus_strain_Jilu_LG135_(KX904728.1) & 99.80 & 99.80 & 95.80 & 99.80 & 99.80 & 99.80 & 99.80 & 99.80 & - & & & \\
\hline B_zhangzhouensis_strain_D61_(MK712418.1) & $\mathbf{1 0 0 . 0 0}$ & 100.00 & 95.90 & 99.70 & $\mathbf{1 0 0 . 0 0}$ & 100.00 & 100.00 & 100.00 & 99.80 & - & & \\
\hline B_zhangzhouensis_strain_LA379_(KY622449.1) & 99.80 & 99.80 & 95.80 & 99.60 & 99.80 & 99.80 & 99.80 & 99.80 & 99.70 & 99.80 & - & \\
\hline BL4 & 99.70 & 99.70 & 95.70 & 99.40 & 99.70 & 99.70 & 99.70 & 99.70 & 99.60 & 99.70 & 99.80 & - \\
\hline
\end{tabular}

Table 6: Sequence similarity matrix of BL5 16S rRNA partial sequence with the other closely related species

\begin{tabular}{|c|c|c|c|c|c|c|c|c|c|}
\hline Sequence & 1 & 2 & 3 & 4 & 5 & 6 & 7 & 8 & 9 \\
\hline B_zhangzhouensis_strain_D61_(MK712418.1) & - & & & & & & & & \\
\hline B_pumilus_strain_FGMZN_9TR_(MK640705.1) & $\mathbf{1 0 0 . 0 0}$ & - & & & & & & \\
\hline B_pumilus_strain_K10_(MK696261.1) & $\mathbf{1 0 0 . 0 0}$ & $\mathbf{1 0 0 . 0 0}$ & - & & & & & & \\
\hline B_pumilus_strain_TR3.1_(MK239935.1) & $\mathbf{1 0 0 . 0 0}$ & $\mathbf{1 0 0 . 0 0}$ & $\mathbf{1 0 0 . 0 0}$ & - & & & & & \\
\hline B_zhangzhouensis_strain_APBSIITMB23 & $\mathbf{1 0 0 . 0 0}$ & $\mathbf{1 0 0 . 0 0}$ & $\mathbf{1 0 0 . 0 0}$ & $\mathbf{1 0 0 . 0 0}$ & - & & & & \\
(MG595384.1) & & & & & & & & & \\
\hline B_pumilus_strain_w19_(MK696249.1) & $\mathbf{1 0 0 . 0 0}$ & $\mathbf{1 0 0 . 0 0}$ & $\mathbf{1 0 0 . 0 0}$ & $\mathbf{1 0 0 . 0 0}$ & $\mathbf{1 0 0 . 0 0}$ & - & & & \\
\hline Bacillus_sp_M-237-10_(KF746904.1) & $\mathbf{9 9 . 8 0}$ & $\mathbf{9 9 . 8 0}$ & $\mathbf{9 9 . 8 0}$ & $\mathbf{9 9 . 8 0}$ & $\mathbf{9 9 . 8 0}$ & $\mathbf{9 9 . 8 0}$ & - & & \\
\hline B_pumilus_strain_FGMZN_9OP_(MK640703.1) & $\mathbf{9 9 . 4 0}$ & $\mathbf{9 9 . 4 0}$ & $\mathbf{9 9 . 4 0}$ & $\mathbf{9 9 . 4 0}$ & $\mathbf{9 9 . 4 0}$ & $\mathbf{9 9 . 4 0}$ & $\mathbf{9 9 . 3 0}$ & - & \\
\hline BL5 & $\mathbf{1 0 0 . 0 0}$ & $\mathbf{1 0 0 . 0 0}$ & $\mathbf{1 0 0 . 0 0}$ & $\mathbf{1 0 0 . 0 0}$ & $\mathbf{1 0 0 . 0 0}$ & $\mathbf{1 0 0 . 0 0}$ & $\mathbf{9 9 . 8 0}$ & $\mathbf{9 9 . 4 0}$ & - \\
\hline
\end{tabular}




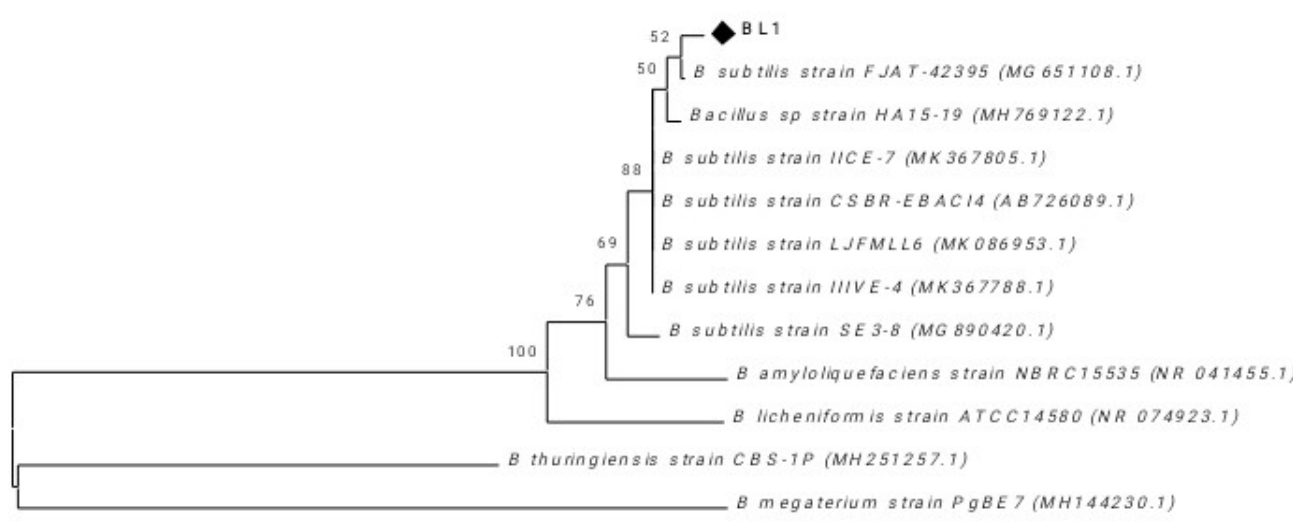

Figure 4: Indicating phylogenetic tree of bacterial culture BL1

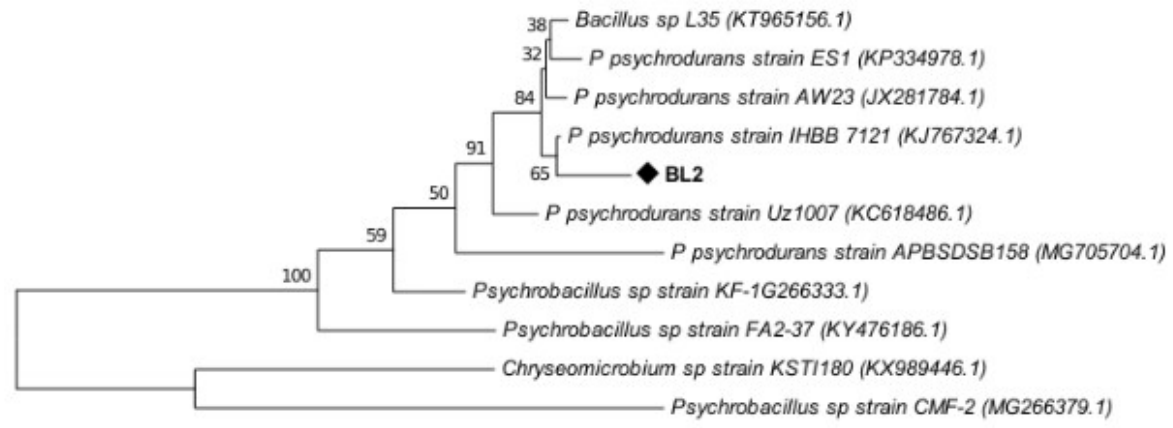

0.02

Figure 5: Indicating phylogenetic tree of bacterial culture BL2



Figure 6: Indicating phylogenetic tree of bacterial culture BL3 


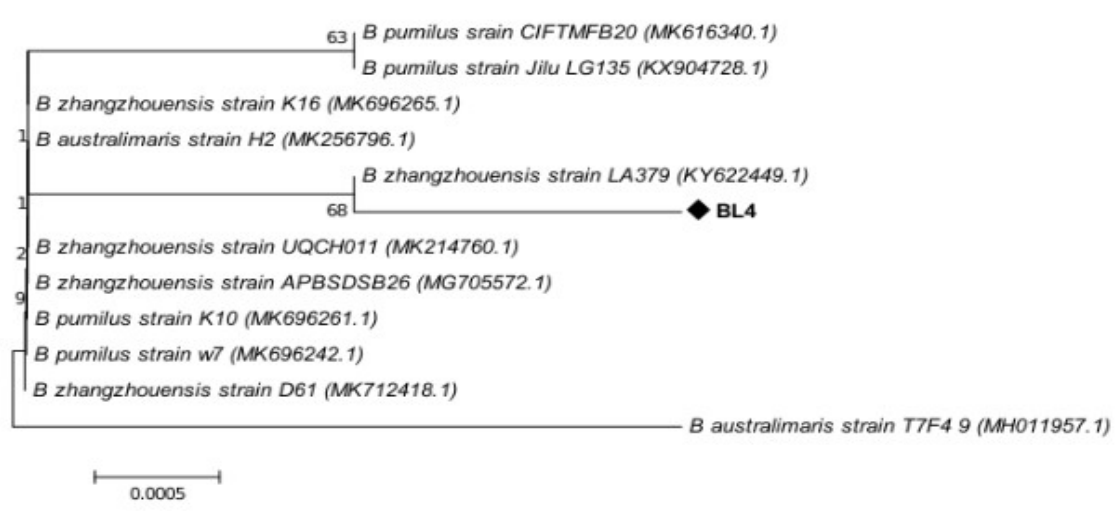

Figure 7: indicating phylogenetic tree of bacterial culture BL4

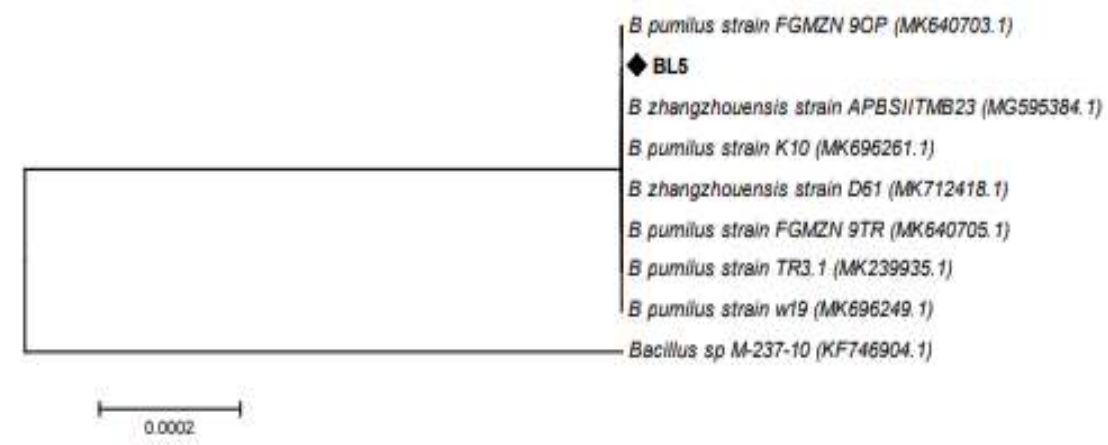

Figure 8: Indicating phylogenetic tree of bacterial culture BL5

\section{DISCUSSION}

Pseudomonadaceae, Enterobacteriaceae, Flavobacteriaceae, Burkholderiaceae, Xanthomonadaceae, and Bacillaceae families are well known plant-associated bacteria [9, 13, 21, 26, 32, 34]. Endophytic bacteria are found in roots, stems, leaves, seeds, fruits, tubers, ovules, and also inside legume nodules $[6,10]$. The study of endophytic bacteria is important, not only for understanding their ecological role in their interaction with plants but also for their possible biotechnological applications, such as bioremediation. From this point of view, an interesting interaction between the endophytic bacterial community and glyphosate herbicidewas observed during enrichment isolation. Only two bacterial species were recovered from the culture medium supplemented by glyphosate, Pseudomonas oryzihabitans and Burkholderia gladioli. The bacterium $P$. oryzihabitans was also recovered from total isolation and presented sensibility to glyphosate. This species has been isolated from different samples, such as soil, water, zones of rice cultivation [8], and moreover, soybean seeds $[\mathbf{4}, \mathbf{2 5}]$. Suggested that these 
bacterial effects could be potentially useful to promote plant growth during seedling acclimatization in orchid species other than the species of origin [7].

Joshi and Fenella [17] revealed a definite pattern in the diversity of culturable epiphytic bacteria, host-dependent colonization, microhabitat localization and biofilm formation which play a significant role in plant-microbe interaction. A novel endophytic filamentous bacterium strain was isolated from wild orchid Grosourdya appendiculata of Thailand [33]. Recently, host specificity has begun to be recognized, using Molecular Plant-Microbe Interactions molecular analysis based on the sequence of ribosomal genes $[\mathbf{1 4}, \mathbf{1 8}, \mathbf{2 3}]$ extensive information on the molecular mechanisms of other bacteria-plant interactions $[5, \mathbf{1 0}]$, there is only limited data on the endophyte-host molecular interactions. It would also be interesting to address whether some of the well-studied molecular mechanisms used by phytopathogenic bacteria [19] are to some extent shared with endophytes. Endophytic bacteria provide useful and rich models to study the genetic expression of bacteria in their natural niches or habitats (inside plants), which are more structured and variable than culture media under controlled laboratory conditions. Nevertheless, very little work has been done on this. Genomic projects are being performed on some endophytic bacteria, such as Azoarcus spp. [3].

Here, in this study, we isolated and identified five different endophytic bacteria from the leaves of epiphytic orchid, $C$. tenufolium. Since all the bacteria belongs to bacillus variety, its identification becomes difficult by using microscopy and biochemical methods. In this situation, genotypic methods will play major role in identifying bacteria. The particular orchid variety shows that it is providing favourable habitat for the bacteria to be alive. Future studies need to prove the presence and accurate identification of microbes from other parts of plants such as root, inflorescence, etc and also how it's beneficial to the plant. Because of human activities, forests and its products are decreasing, especially trees; now, epiphytic orchids are facing the problem of endanger. So, there is an urgent need of action to conserve the orchid and other vulnerable plants and its endophytic diversity for upcoming generation.

\section{CONCLUSION}

Endophytic bacteria isolated from $C$ tenuifolium were diverse but unique in shape (all are bacilli). However, genotypic characterization provides better knowledge 
on species level identification. Epiphytic orchids mostly found on the trees of forest. In this study, special interest were shown to identify, document and conserve diversified endophytes from vulnerable epiphytic plants for future generation. Along with conservation, the uses of these organisms were also need to be studied urgently.

\section{ACKNOWLEDGEMENT}

We are grateful to Mangalore University for laboratory and technical assistance.

\section{REFERENCES}

[1] Arundhati Das, Jagdish Krishnaswamy, Kamaljit S Bawa, M C Kiran, V Srinivas, N Samba Kumar, K Ullas Karanth, Prioritisation of conservation areas in the Western Ghats, India, Biological Conservation, 2006, 133(1): 16-31 https://doi.org/10.1016/j.biocon.2006 .05 .023

[2] Azevedo J L, Maccheroni W, Jr., Pereira, J O and de Araujo W L,Endophytic microorganisms: A review on insect control and recent advances on tropical plants. Electron. J. Biotechnol. 2000, 3, No. 1. Online publication.

[3] Battistoni F, Bartels D, Kaiser O, Marie Reamon-Buettner S, Hurek T, and Reinhold-Hurek B, Physical map of the Azoarcus sp. strain $\mathrm{BH} 72$ genome based on a bacterial artificial chromosome library as a platform for genome sequencing and functional analysis. FEMS (Fed. Eur. Microbiol. Soc.) Microbiol. Lett. 2005, 249:233240. https://doi.org/10.1016/j.femsle. $\underline{2005.06 .015}$

[4] Belimov A A, Safronova V I, Sergeyeva $\mathrm{T}$ A, Egorova $\mathrm{T} \mathrm{N}$, Matveyeva V A, Tsyganov V E, Borisov A Y, Tikhonovich I A, Kluge C, Preisfeld A, Dietz K J and Stepanok V V, Characterization of plant growth promoting rhizobacteria isolated from polluted soils and containing 1-aminocyclopropane-1carboxylate deaminase. Can. J. Microbiol. 2001, 47: 642-652.

[5] Ben Lugtenberg, Introduction to Plant-Microbe Interactions, Book: Principles of Plant-Microbe Interactions, $\quad 2015: 1$ to 2 https://doi.org/10.1007/978-3-319$\underline{08575-3 \quad 1}$

[6] Darsha S., Arivukarasu R., Jayashankar M., Mohammed Ali Saeed, The Molecular identification of root nodule bacteria from edible crops of Fabaceae family, Kerala; Journal of Applied and Natural 
Science, 2018, 10(3) :1063-

1065 https://doi.org/10.31018/jans.v1

$\underline{0 \mathrm{i} 3.1864}$

[7] Deise Cristina Faria, Armando Cavalcante Franco Dias, ItamarSoaresMelo, Francisco Eduardo de Carvalho Costa, Endophytic bacteria isolated from orchid and their potential to promote plant growth. World Journal of Microbiology and Biotechnology, 2013, 29(2):217-221.

https://doi.org/10.1007/s11274-012$\underline{1173-4}$

[8] Dussart L, Dupont J P, Zimmerlin I, Lacroix M, Saiter J M, Junter G A and Jouenne T, Occurrence of sessile Pseudomonas oryzihabitans from a karstied chalk aquifer. Water Res. 2003, 37, 1593-1600.

[9] Garbeva P, Overbeek L, Vuurde J, Elsas J, Analysis of endophytic bacterial communities of potato by plating and denaturing gradient gel electrophoresis (DGGE) of $16 \mathrm{~S}$ rDNA based PCR fragments. Microb. Ecol. 2001: 41: 369-383.

[10] Giles E D Oldroyd, J Allan Downie, Calcium, kinases and nodulation signalling in legumes: Nature Reviews Molecular Cell Biology,
2004 ,

5 (7): 566 to 576 https://doi.org/10.1 $\underline{038 / \mathrm{nrm} 1424}$

[11] Girlanda M, Perotto S, MoenneLoccoz Y, Bergero R, LazzariA, Defago $\mathrm{G}$, et al. Impact of biocontrol Pseudomonas fluorescens CHA0and a genetically modified derivative on the diversity of culturable fungi in the cucumber rhizosphere. Appl Environ Microbiol 2001, 67:1851-64.

[12] Gogoi K, R. L. Borah, Raju Das, Rajendra Yonzone. Present Status of Orchid Species Diversity Resources of Joypur Reserve Forest of Dibrugarh District (Assam) of North East India International Journal of Modern Botany, 2012, 2(3): 4767.https://doi.org/10.5923/j.ijmb.20 $\underline{120203.03}$

[13] Halda-Alija L, Identification of indole-3-acetic acid producing freshwater wetland rhizosphere bacteria associated with Juncus effuses L. Can. J. Microbiol. 2003, 49: 781-787.

[14] Jacquot, E, van Tuinen $D$, Gianinazzi $\mathrm{S}$ and GianinazziPearson V, Monitoring species of arbuscular mycorrhizal fungi in 
plants and in soil by nested PCR: Application to the study of the impact of sewage sludge. Plant Soil. 2000, 226:179-188.

[15] Jalal J S and Jayanthi J, Endemic orchids of peninsular India: a review. Journal of Threatened Taxa 2012, 4(15), 2012: $\quad 3415-$ 3425 https://doi.org/10.11609/jott.o $\underline{3091.3415-25}$

[16] Jayasri.M A, S Banerjee, A Das, P Chakrabort, K Suthindhir (Antioxidant and Antimicrobial Activity of Araucaria cookii and Brassaia actinophyla; Pakistan Journal of Biological Sciences, 2014, $17(5): 715-719$ https://doi.org/10.3923/pjbs.2014.7 $\underline{15.719}$

[17] Joshi S R, Fenella Mary War Nongkhlaw, Distribution pattern analysis of epiphytic bacteria on ethnomedicinal plant surfaces: A micrographical and molecular approach, Journal of Microscopy and Ultrastructure 2014, 2(1):34. https://doi.org/10.1016/j.jmau.2014. $\underline{02.003}$

[18] Kjoller R, and Rosendahl $\mathrm{S}$, Detection of arbuscular mycorrhizal fungi (Glomales) in roots by nested
PCR and SSCP (single stranded conformation polymorphism). Plant Soil, 2000, 226:189-196.

[19] Klaas A E van't Slot, Wolfgang Knogge, A Dual Role for Microbial Pathogen-Derived Effector Proteins in Plant Disease and Resistance Critical Reviews in Plant Sciences, 2002, 21(3): 229- 271 https://doi.org/10.1080/0735$\underline{260291044223}$

[20] Kumar P, Jalal J S, Rawat G S (2007), Orchidaceae, Chotanagpur, state of Jharkhand, India. Check List 3(4):

297-304

https://doi.org/10.15560/3.4.297

[21] Loiret F, Ortega E., Kleiner D, Ortega-Rodes P, Rodes R, Dong Z, A putative new endophytic nitrogenfixing bacterium Pantoea sp. from sugarcane. J. Appl. Microbiol. 2004, 97: 504-511.

[22] Maridass M, Hussain Z M I, Raju G, Phytochemical survey of orchids in the Tirunelveli Hills of South India. Ethnobotanical Leaflets12, 2008: 705-712.

[23] Mónica Rosenblueth and Esperanza Martínez-Romero Bacterial Endophytes and Their Interactions with Hosts, The American 
Phytopathological Society 2006,19(8): 827-837.

[24] Muniappan Ayyanar, Savarimuthu Ignacimuthu, Ethnobotanical survey of medicinal plants commonly used by Kanitribals in Tirunelveli hills of Western Ghats, India, Journal of Ethnopharmacology,

2011,134 (3): 851 -

864 https://doi.org/10.1016/j.jep.20

$\underline{11.01 .029}$

[25] Oehrle N W, Karr D B, Kremer R J and Emerich D W, Enhanced attachment of Bradyrhizobium japonicum to soybean through reduced root colonization of internally seed borne microorganisms. Can. J. Microbiol. 2000, 46: 600-606.

[26] Park M., Kim C, Yang J, Lee H, Shin W, Kim S, Sa T, Isolation and characterization of diazotrophic growth promoting bacteria from rhizosphere of agricultural crops of Korea. Microbiol. Res. 160, 2005: 127-133.

[27] Ponnala Raghavendra, Prakash M Halami, Screening, selection and characterization of phytic acid degrading lactic acid bacteria from chicken intestine; International
Journal of Food Microbiology, $2009133(1-2)$ :

129 to 134 . https://doi.org/10.1016/j. ijfoodmicro.2009.05.006

[28] Ramesh Marasini, Susan Joshi, Antibacterial and Antifungal Activity of Medicinal Orchids Growing in Nepal; Journal of Nepal Chemical Society, 2013, 29:104 109

https://doi.org/10.3126/jncs.v29i0.9 $\underline{259}$

[29] Shonila. A. Bhagwat, Cheppudira. G. Kushalappa, Paul H. Williams and Nick Brown Conservation biology, 2005: 1853-1862, Society for Conservation Biology, Doi: 1111/j.15231739.2005.00248.x

[30] SturzA V, Christie B R and Nowak J, Bacterial endophytes: Potential role in developing sustainable systems of crop production. CRC C.R. Rev. Plant Sci. 2000, 19: 1-30.

[31] Tan Z, Hurek T, and ReinholdHurek B, Effect of N-fertilization, plant genotype and environmental conditions on nifH gene pools in roots of rice. Environ. Microbiol. 2003, 5:1009-1015.

[32] Unno Y, Okubo K, Wasaki J, Shinano T, Osaki M, Plant growth 
promotion abilities and microscale bacterial dynamics in the rhizosphere of Lupin analysed by phytate utilization ability. Environ. Microbiol. 2005, 7: 396-404.

[33] WipapornNgaemthao, Tawanmol Pujchakarn, Suwanee Chunhametha, Chanwit Suriyachadkun Verrucosisporaendophytica sp. nov., isolated from the root of wild orchid (Grosourdya appendiculata (Blume) Rchb.f.).International Journal of Systematic and Evolutionary Microbiology,2017, 67(12): 51145119

https://doi.org/10.1099/ijsem.0.0024 $\underline{25}$

[34] Young C, Kampfer P, Shen F, Lai W, Arun A, Chryseobacterium formosense sp. nov., isolated from the rhizosphere of Lactuca sativa L. (garden lettuce). Int. J. Syst. Evol. Microbiol. 2005, 55: 423-426. 